\title{
Positive correlation between soil bacterial metabolic and plant species diversity and bacterial and fungal diversity in a vegetation succession on Karst
}

\author{
Xun-Yang He $\cdot$ Ke-Lin Wang $\cdot$ Wei Zhang • \\ Zhi-Hui Chen • Yong-Guan Zhu • \\ Hong-Song Chen
}

Received: 5 November 2007 / Accepted: 5 March 2008/Published online: 2 April 2008

(C) Springer Science + Business Media B.V. 2008

\begin{abstract}
The hypothesis that positive links exist among plant taxonomic diversity, belowground microbial taxonomic and metabolic diversities was tested for four secondary vegetation successional stages (tussock (T), shrub (S), secondary forest (SF) and primary forest (PF)) in Huanjiang county, SW China. Soil bacterial communities were characterized by DNA fingerprinting and metabolic profiling. Along the succession, Shannon diversity indices followed the order $\mathrm{SF}>\mathrm{PF}>\mathrm{S}>\mathrm{T}$ for plant taxonomic diversity, $\mathrm{T}>\mathrm{SF}>\mathrm{PF}>\mathrm{S}$ for bacterial operational taxonomic diversity, $\mathrm{SF}>\mathrm{T}>\mathrm{S}>\mathrm{PF}$ for fungal operational taxonomic diversity, and $\mathrm{SF}>\mathrm{PF}>\mathrm{S}>\mathrm{T}$ for bacterial metabolic diversity. Significant positive correlations were found between bacterial and fungal taxonomic diversities. However, there was no significant corre-
\end{abstract}

Responsible Editor: Angela Hodge.

X.-Y. He • K.-L. Wang $(\bowtie) \cdot$ W. Zhang $\cdot$ Z.-H. Chen •

H.-S. Chen

Institute of Subtropical Agriculture,

Chinese Academy of Sciences,

Changsha 410125, China

e-mail: kelin@isa.ac.cn

X.-Y. He

Graduate School of Chinese Academy of Science,

Beijing 100039, China

Y.-G. Zhu

Research Center for Eco-Environmental Sciences,

Chinese Academy of Sciences,

Beijing 100085, China lation between soil microbial taxonomic diversity and bacterial metabolic diversity. Two-way ANOVA revealed that vegetation and season, as well as their interaction, had significant effects on soil microbial (fungal and bacterial) taxonomic diversities, but that there were no seasonal effects on metabolic diversity. However, PCA and MANOVA revealed highly significant differences among the bacterial community-level physiological profiles, reflecting the successional sequence. The findings from this survey support the notion that there are strong interactions between aboveground and belowground communities and suggest that bacterial metabolic and plant taxonomic diversities, but not microbial taxonomic and metabolic diversities, can be correlated.

Keywords BIOLOG - Microbial community PCR-DGGE · Seasonal variation · Vegetation effects

\begin{tabular}{|c|c|}
\hline \multicolumn{2}{|c|}{ Abbreviations } \\
\hline CLPP & $\begin{array}{l}\text { Community-level physiological profil- } \\
\text { ing pattern }\end{array}$ \\
\hline DGGE & Denaturing gradient gel electrophoresis \\
\hline EDTA & Ethylene diamine tetraacetic acid \\
\hline MANOVA & Multivariate analysis of variance \\
\hline PCA & Principle component analysis \\
\hline $\mathrm{PC}$ & Principle component \\
\hline PCR & polymerase chain reaction \\
\hline UPGMA & $\begin{array}{l}\text { Unweighted pair group method with } \\
\text { arithmetic mean }\end{array}$ \\
\hline
\end{tabular}




\section{Introduction}

Soil ecosystems are highly complex, containing a tremendous amount of species. Indigenous microbial populations in soil are of fundamental importance for ecosystem functioning due to their capacity to determine nutrient cycles (Doran and Zeiss 2000). Land use change represents the most substantial human alteration of ecosystems, dramatically altering plant community compositions and typically lowering their diversity (Vitousek et al. 1997). The direct effects of changes in plant community composition and/or diversity on ecosystem processes have been evaluated in a number of studies (Naeem and Li 1997; Tilman 1999), as have their effects on soil microbial diversity (Bossio et al. 2005; Crecchio et al. 2007; Lupway et al. 1998; Yao et al. 2006). The relationship between aboveground plant diversity and belowground microbial diversity has also been examined: Carney and Matson (2006) studied the influence of tropical plant diversity on soil microbial communities within an experimental system, Costa et al. (2006) studied the effects of different crops on bacterial and fungal rhizosphere communities using molecular fingerprinting, and De Deyn and Van der Putten (2005) reviewed the link between aboveground and belowground diversity. However, little is known about how soil microbes respond to changes of plant diversity in secondary vegetation succession.

Karst is a distinctive topography, created by the action of acidic water on carbonate bedrock, such as limestone, dolomite, or marble. Globally, the Karst landscape occupies $22,000,000 \mathrm{~km}^{2}$, accounting for $15 \%$ of the total land area (Yuan 1991). The Karst area of SW China covers $550,000 \mathrm{~km}^{2}$ (Li et al. 2002), but Karst also occurs at the European Mediterranean seacoast and the east coast of South America (Ouyang 1998). An increasing human population and other heavy anthropogenic impacts have seriously damaged the vegetation in the Karst region of SW China (Yao et al. 2001). Proper ecosystem functioning is seriously threatened by soil degradation, which impairs water and nutrient flows, and ultimately plant growth (Pan and Cao 1999). Microbial communities are an important component of soil quality and may serve as indicators for changes in soil health (Scow et al. 1998), but the effects of ecosystem degradation on soil microbial communities are largely unknown.
In this study, involving investigations on microbial diversity at two seasonal time points along a vegetation succession, we addressed the question of whether positive links exist among plant taxonomic diversity, belowground microbial taxonomic and metabolic diversities; Moreover, seasonal variations on soil microbial taxonomic diversity were discussed.

\section{Materials and methods}

\section{Study sites}

Four secondary vegetation succession stages were selected around the Guzhou village, Huanjiang county, Guangxi province in SW China $\left(24^{\circ} 50^{\prime} \mathrm{N}\right.$, $107^{\circ} 55^{\prime}$ E). A subtropical mountainous monsoon climate dominates in the area with a mean annual rainfall of $1389 \mathrm{~mm}$ and a mean annual air temperature of $18.5^{\circ} \mathrm{C}$. The wet season with $70 \%$ of annual precipitation lasts from April until end of August. The local Karst formation consists of layers of limestone, arranged horizontally with well developed vertical fissures. The shallow soils with depth of only 0 $20 \mathrm{~cm}$ have been mollic inceptisols, but are largely eroded or degraded due to overuse, as is vegetation cover.

Three secondary successional communities (tussock (T), shrub (S), and secondary forest (SF)) were identified at the study site. The $\mathrm{T}$ community, in an area not cultivated for 3 years but suffering from substantial anthropogenic disturbance (grazing and mowing), is located in a peak-cluster depression at lower altitude and with less steep slopes than the others studied communities located in sharp hillsides. The S and SF communities had only experienced little occasional disturbance for 18 years and 50 years, respectively, due to the implementation of conservation projects in the area. A neighboring undisturbed primary forest community (PF) $\left(25^{\circ} 07^{\prime} 54^{\prime \prime} \mathrm{N}, 108^{\circ} 00^{\prime}\right.$ $08^{\prime \prime}$ E) in the Mulun National Nature Reserve was selected as a control ecosystem characterized by different dominant species and undisturbed by human action. For each of the stages S, SF, and PF a single sampling site (with dominant species typical of the study region) was selected. For the $\mathrm{T}$ successional stage three sampling sites were chosen to account for the larger variability in plant cover observed in this initial stage of succession. The plots for plant survey 
and soil sampling were $5 \mathrm{~m} \times 5 \mathrm{~m}$ for the T, $20 \mathrm{~m} \times$ $10 \mathrm{~m}$ for the $\mathrm{S}$, and $40 \mathrm{~m} \times 20 \mathrm{~m}$ for both the SF and $\mathrm{PF}$ vegetation successional stages.

\section{Plant survey and soil sampling}

Each plot (except for $\mathrm{T}$ ) was subdivided into four rectangular subplots from which three were chosen for vegetation surveys in June 2006. In the SF and PF communities, each subplot (quadrat) was divided into three layers (arboreal, shrubby and herbaceous), whereas the vegetation in the $\mathrm{S}$ community subplots was divided into two layers (shrubby and herbaceous). For the arboreal layers, all woody stems (including climbing plants) with diameters at breast height $(\mathrm{DBH}) \geq 2.5 \mathrm{~cm}$ were tallied, identified and measured for DBH to the nearest $0.1 \mathrm{~cm}$. For the shrubby (tree seedlings and woody climbing plants $<2.5 \mathrm{~cm}$ stem diameter) and herbaceous (herbaceous climbing plants and ferns) layers the fascicles and heights of each plant species were tallied. All plant species were identified and their percent cover was visually estimated.

From each plot $(\mathrm{T})$ or subplot (S, SF, PF), five to eight soil sub-samples to a depth of $15 \mathrm{~cm}$ were collected along an S-shaped transect, using a soil corer $3 \mathrm{~cm}$ in diameter. The soil sub-samples were pooled to one composite sample per plot $(\mathrm{T})$ or subplot (S, SF, PF), according to the method of Klose et al. (2004), yielding three replicates per successional stage. Sampling was carried out in June and December 2006, corresponding to the wet and dry seasons, respectively. The soil samples were stored in plastic bags in an icebox for transport to the laboratory, where they were kept at $4^{\circ} \mathrm{C}$ until analyzed. Sieved soil samples $(<2 \mathrm{~mm})$ were divided into three portions. One part of soil was stored at $-70^{\circ} \mathrm{C}$ for PCR-DGGE fingerprinting, another part was stored at $4^{\circ} \mathrm{C}$ for BIOLOG profile analyses, and a further part was air dried for physical and chemical analyses. Soil properties are reported in Table 1.

DNA extraction and community fingerprinting

Total bacterial community DNA was extracted from $500 \mathrm{mg}$ fresh soil, using the commercial FastDNA Spin Kit for Soil (BIO101, Vista, CA, USA) according to the manufacturer's protocol. Prior to PCR, the DNA was further purified with the GeneClean kit
(BIO101). PCR was carried out with a PTC-100 thermal cycler (M.J. Research, Inc., Watertown, MA), and the primer systems targeted the small subunit rRNA genes of bacteria and fungi. For bacteria, amplification of 16S rDNA sequences was performed with the primer pair F984GC/R1378, yielding a 433 bp DNA fragment suitable for total community fingerprinting (Heuer et al. 1999). For fungi, the NS1 primer and the fungus-specific primer GCfung (May et al. 2001) were used to amplify the $5^{\prime}$ end of the $18 \mathrm{~S}$ rDNA (370 bp). Both F984GC and GCfung had GC clamps of $40 \mathrm{bp} \mathrm{DNA}^{1}$ (Muyzer et al. 1993), as needed for optimal DGGE analysis (Ferris et al. 1996). All PCR reactions were carried out in $50 \mu \mathrm{l}$ with $0.02 \%(\mathrm{w} / \mathrm{v})$ bovine serum albumin and $200 \mathrm{nM}$ of each primer for bacteria, and $400 \mathrm{nM}$ for fungi, $200 \mu \mathrm{M}$ dNTPs (QIAGEN Inc., Hilden, Germany), 1.5U of HotStarTaq DNA polymerase (QIAGEN Inc., Hilden, Germany), and $1 \mu \mathrm{l}$ (bacteria) or $4 \mu \mathrm{l}$ (fungi) of 1:9 diluted template DNA $\left(5 \sim 30 \mathrm{ng} \mu l^{-1}\right)$. For bacteria the touchdown PCR protocol of Gelsomino and Cacco (2006) was used with initial denaturation at $95^{\circ} \mathrm{C}$ for $15 \mathrm{~min}$. For fungi the initial denaturation $\left(95^{\circ} \mathrm{C}\right.$ for $\left.15 \mathrm{~min}\right)$, was followed by 35 amplification cycles $\left(95^{\circ} \mathrm{C}\right.$ for $1 \mathrm{~min}, 57^{\circ} \mathrm{C}$ for $1 \mathrm{~min}, 72^{\circ} \mathrm{C}$ for $2 \mathrm{~min}$ ), and a final extension at $68^{\circ} \mathrm{C}$ for $10 \mathrm{~min}$, and cooling to $4^{\circ} \mathrm{C}$.

DGGE was performed using a DCode ${ }^{\mathrm{TM}}$ Universal Mutation Detection System (Bio-Rad Laboratories, Hercules, CA, USA). $20 \mu \mathrm{l}$ of PCR products were loaded on $6 \%$ (bacteria) or $8 \%$ (fungi) $\mathrm{wt} / \mathrm{vol}$ polyacrylamide gels in $1 \times$ TAE buffer (40 mM Tris base, $20 \mathrm{mM}$ acetic acid, and $1 \mathrm{mM}$ disodium EDTA, $\mathrm{pH} 8.3$ ) containing a linear chemical gradient of 40 $60 \%$ (bacteria) or $15-35 \%$ (fungi) denaturant (100\% denaturant corresponding to $7 \mathrm{M}$ urea in $40 \%(\mathrm{v} / \mathrm{v})$ of deionized formamide). Electrophoreses were run in $1 \times$ TAE buffer at $60^{\circ} \mathrm{C}$ with a constant voltage of $100 \mathrm{~V}$ for $7 \mathrm{~h}$. Images of gels stained with ethidium bromide were recorded with a Polaroid camera system (SYNGENE Inc., USA).

Bacterial community metabolic (BIOLOG) profiles

Community-level physiological profiling patterns of soil bacterial communities (CLPPs) were assessed

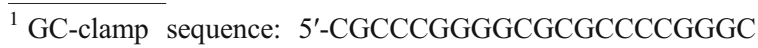
GGGGCGGGGGCACGGGGGG-'
} 
Table 1 Soil parameters in the secondary vegetation succession stages tussock (T), shrub (S), secondary forest (SF), and primary forest $(\mathrm{PF})^{\mathrm{a}}$

\begin{tabular}{|c|c|c|c|c|}
\hline Variables & $T$ & $S$ & $\mathrm{SF}$ & $\mathrm{PF}$ \\
\hline $\mathrm{pH}\left(1: 2.5 \mathrm{H}_{2} \mathrm{O}\right)$ & $6.82 \pm 0.10 \mathrm{a}$ & $7.72 \pm 0.02 b$ & $7.24 \pm 0.38 \mathrm{ab}$ & $7.99 \pm 0.02 b$ \\
\hline $\operatorname{SOM}\left(\mathrm{g} \mathrm{kg}^{-1}\right)$ & $22.73 \pm 2.23 \mathrm{a}$ & $59.9 \pm 4.00 \mathrm{~b}$ & $97.48 \pm 6.84 \mathrm{c}$ & $90.04 \pm 10.69 c$ \\
\hline Total N $\left(\mathrm{g} \mathrm{kg}^{-1}\right)$ & $1.16 \pm 0.15 \mathrm{a}$ & $3.53 \pm 0.15 b$ & $5.68 \pm 0.4 c$ & $4.82 \pm 0.49 c$ \\
\hline $\mathrm{C} / \mathrm{N}$ & $11.51 \pm 0.49 b$ & $9.81 \pm 0.24 \mathrm{a}$ & $9.95 \pm 0.19 a$ & $10.79 \pm 0.22 \mathrm{ab}$ \\
\hline $\operatorname{CEC}\left(\mathrm{cmol}_{(+)} \mathrm{kg}^{-1}\right)$ & $9.88 \pm 2.25 \mathrm{a}$ & $28.05 \pm 0.55 b$ & $34.62 \pm 1.95 b$ & $32.56 \pm 3.13 b$ \\
\hline Sand $(2-0.05 \mathrm{~mm})(\%)$ & $17.38 \pm 4.64 \mathrm{c}$ & $8.21 \pm 0.97 \mathrm{ab}$ & $15.54 \pm 1.21 \mathrm{cb}$ & $3.83 \pm 1.16 \mathrm{a}$ \\
\hline Silt $(0.05-0.002 \mathrm{~mm})(\%)$ & $53.39 \pm 1.62 \mathrm{c}$ & $38.43 \pm 0.62 b$ & $33.93 \pm 3.03 \mathrm{a}$ & $30.16 \pm 2.34 \mathrm{a}$ \\
\hline Clay <0.002 mm (\%) & $28.35 \pm 4.76 \mathrm{a}$ & $51.2 \pm 0.64 b$ & $47.88 \pm 1.68 b$ & $45.03 \pm 3.47 \mathrm{~b}$ \\
\hline Bulk density ( $\mathrm{kg} \mathrm{dm}^{-3}$ ) & $1.35 \pm 0.03 c$ & $1.17 \pm 0.03 b$ & $0.88 \pm 0.03 \mathrm{a}$ & $0.86 \pm 0.07 \mathrm{a}$ \\
\hline
\end{tabular}

${ }^{a}$ Sampled in June 2006. Values are the means of three replicates with associated standard errors. Means in a row with the same letter are not significantly different at $P<0.05$ (Duncan)

using BIOLOG ${ }^{\circledR}$ 96-well Eco-Microplates (Biolog Inc., Hayward, USA) with 31 different carbon sources and a negative control (water), replicated three times in each microplate. Microorganisms were extracted from the soil samples according to Zak et al. (1994). $150 \mu \mathrm{l}$ of a 1:1000 (w/v) soil suspension were dispensed into each of the 96 wells and then the microplates were incubated at $25^{\circ} \mathrm{C}$ in the dark for 7 days. Color development (reflecting carbon utilization) in the wells was followed by absorbance measurements at $590 \mathrm{~nm}$ every $24 \mathrm{~h}$ using a Microplate E-Max Reader (Bio-Rad).

\section{Data analysis}

Banding patterns of DGGE profiles were analyzed with the Bio-Rad Quantity One software to calculate Dice distances among lanes and draw UPGMA similarity dendrograms (Crecchio et al. 2004). After subtracting the background from the gradient gel image by the strip method, lane background subtraction of the nonlinear background was achieved by using the rolling disk mechanism with an intensity of 5. For identification and quantification of the DNA bands the tolerance and optimization parameters were set to $1 \%$. To eliminate variation in band intensity, caused by different amounts of loaded PCR product relative ribotype intensities per lane were calculated by dividing the intensity of the corresponding band by the sum of the intensities of all bands within the lane.

In the analysis of the BIOLOG data the midpoint (72-h incubation) in overall color development was used as a reference point of color development changes with time (Garland 1996). The number of positive wells were counted according to Glimm et al. (1997), with an $\mathrm{OD}$ correction to 2 when $\mathrm{OD}>2$ as these positive wells could contribute to the metabolic diversity. The CLPP data were analyzed by PCA after accounting for the different initial cell densities (Garland 1997) and logarithmic transformation (Weber et al. 2007). Principal components were calculated on the basis of the covariance matrix, since all variables were based on the same scale and may therefore contain information (Weber et al. 2007). MANOVA was conducted for statistical comparisons of community catabolic profiles among treatments (Glimm et al. 1997).

For the plant, DGGE, and utilization data, Shannon indices were calculated as $\mathrm{H}^{\prime}=-\sum\left(\mathrm{p}_{\mathrm{i}}\right)\left(\ln \mathrm{p}_{\mathrm{i}}\right)$ (Magurran 2004), where $\mathrm{p}_{\mathrm{i}}$ is (a) the importance value of the $i$ th plant species, which was calculated as the sum of the relative density, relative abundance and relative frequency for arboreal layer, and as the sum of the relative height and relative cover for shrubby and herbaceous layer in each plot, respectively (Ou et al. 2005), (b) the percentage of the total intensity accounted for by the $i^{\text {th }}$ band (Müller et al. 2002), or (c) the total coloration accounted for by the $i^{\text {th }}$ substrate (Zak et al. 1994), respectively. Here, Shannon diversity indices were chosen, because they do not only reflect richness, but also evenness of communities (Magurran 2004). Shannon diversities were compared by two-way analysis of variance (ANOVA), using SPSS11.5 (SPSS Inc., Chicago, USA) software. Vegetation and sampling time were used as fixed factors. Comparisons among successional stages were made using Duncan's test at $P<0.05$. 


\section{Results}

Plant survey

The three $\mathrm{T}$ communities had different dominant species (Table 2). The shrubby layer of the $\mathrm{S}$ and the arboreal layer of the SF communities shared the same dominant evergreen broadleaved species (i.e. Bauhinia brachycarpa var.cavaleriei), which was one

Table 2 The dominant plant species for a vegetation succession on Karst ${ }^{\mathrm{a}}$

\begin{tabular}{|c|c|c|}
\hline Stages & Layer & Ranking of dominant plant species \\
\hline $\mathrm{T} 1$ & $\mathrm{H}$ & $\begin{array}{l}\text { Imperata cylindrica }(0.27) \\
\text { Selaginella delicatula }(0.21) \\
\text { Ficus tikoua }(0.19)\end{array}$ \\
\hline $\mathrm{T} 2$ & $\mathrm{H}$ & $\begin{array}{l}\text { Microstegium vegans }(0.29) \\
\text { Erigeron acer }(0.23) \\
\text { Neyraudia reynaudiana }(0.2)\end{array}$ \\
\hline $\mathrm{T} 3$ & $\mathrm{H}$ & $\begin{array}{l}\text { Apluda mutica }(0.52) \\
\text { Lysimachia alfredii var. alfredii }(0.13) \\
\text { Sanicula chinensis }(0.11)\end{array}$ \\
\hline $\mathrm{S}$ & $\mathrm{S}$ & $\begin{array}{l}\text { Bauhinia brachycarpa var.cavaleriei }(0.37) \\
\text { Broussonetia papyrifera }(0.13) \\
\text { Alchornea trewioides }(0.1)\end{array}$ \\
\hline & $\mathrm{H}$ & $\begin{array}{l}\text { Pueraria lobata }(0.27) \\
\text { Imperata cylindrica }(0.19) \\
\text { Paederia scandens var. tomentosa }(0.08)\end{array}$ \\
\hline SF & $\mathrm{A}$ & $\begin{array}{l}\text { Bauhinia brachycarpa var.cavaleriei }(0.24) \\
\text { Sterculia euosma }(0.15) \\
\text { Phoebe calcarea }(0.14)\end{array}$ \\
\hline & $\mathrm{S}$ & $\begin{array}{l}\text { Bauhinia championii var. championii }(0.17) \\
\text { Dalbergia hancei }(0.1) \\
\text { Lonicera japonica }(0.06)\end{array}$ \\
\hline & $\mathrm{H}$ & $\begin{array}{l}\text { Nephrolepis auriculata }(0.36) \\
\text { Neyraudia reynaudiana }(0.13) \\
\text { Drynaria roosii }(0.1)\end{array}$ \\
\hline $\mathrm{PF}$ & A & $\begin{array}{l}\text { Platycarya longipes }(0.21) \\
\text { Boniodendron minius }(0.21) \\
\text { Rapanea neriifolia }(0.19)\end{array}$ \\
\hline & $\mathrm{S}$ & $\begin{array}{l}\text { Ampelocalamus calcareous }(0.16) \\
\text { Rapanea neriifolia }(0.12) \\
\text { Murraya euchrestifolia }(0.09)\end{array}$ \\
\hline & $\mathrm{H}$ & $\begin{array}{l}\text { Carex sp. }(0.37) \\
\text { Clematis florida }(0.16) \\
\text { Cymbidium cyperifolium }(0.07)\end{array}$ \\
\hline
\end{tabular}

${ }^{\mathrm{a}} \mathrm{H}, \mathrm{S}$ and A refer to the herbaceous, shrubby and arboreal layer, respectively. Value in parentheses indicates the important value of plant species (see associated section in Materials and methods). For succession stage abbreviations see Table 1 of prevalent evergreen broadleaved species in the study area. The SF and PF plant communities belong to the evergreen broadleaved forest and evergreendeciduous broadleaved mixed forest, respectively. The tree layer of the SF community was dominated by the evergreen broadleaved species (Bauhinia brachycarpa var.cavaleriei, Sterculia euosma, Phoebe calcarea; Table 2). A completely different set of species, including two deciduous arboreal trees (Platycarya longipes and Boniodendron minius) and one evergreen arboreal tree (Rapanea neriifolia), were dominant in PF (Table 2). Plant species diversity in the four succession stages followed the order: $\mathrm{SF}>\mathrm{PF}>\mathrm{S}>\mathrm{T}$, with significant differences between the T, S, and SF communities (Fig. $4 \mathrm{a}$ ).

\section{Microbial taxonomic diversity}

Variability among sample replicates in the composition of the bacterial communities was considerable (Fig. 1a). At the summer and winter sampling times the bacterial communities from PF soils were distinct from those of the other soils, with low variability among replicates (59-76\% similarity). Conversely, the communities in the $\mathrm{S}$ and $\mathrm{T}$ soils showed more variability, ranging between $42-86 \%$ and $42-66 \%$ similarity, respectively. Seasonal community differences were bigger than those among sample replicates (Fig. 2a). In contrast to the bacterial communities the fungal communities (Fig. 1b) showed even more variability, but also more distinctly dominant ribotypes. Variability was highest among replicates of the PF succession stage (12-50\% similarity, Fig. 2b) with the consequence that these fungal communities could not be distinguished from the other ones.

Bacterial community metabolic (BIOLOG) diversity

The catabolic capability of soil bacterial communities differed considerably among successional stages. PCA on bacterial CLPPs showed that PC1 accounted for $28.1 \%$ and $\mathrm{PC} 2$ for $17.7 \%$ of the total variance (Fig. 3). A multivariate analysis (Wilkinson's lambda) on CLPP differences was conducted, using the first five PCs which account for $75.1 \%$ of total variation. First, the comparisons among four treatments resulted in an F-criterion of 7.19 at 35, 53 degrees of freedom $(p<0.001)$, indicating significant differences of CLPPs among the bacterial communities. Subsequent 


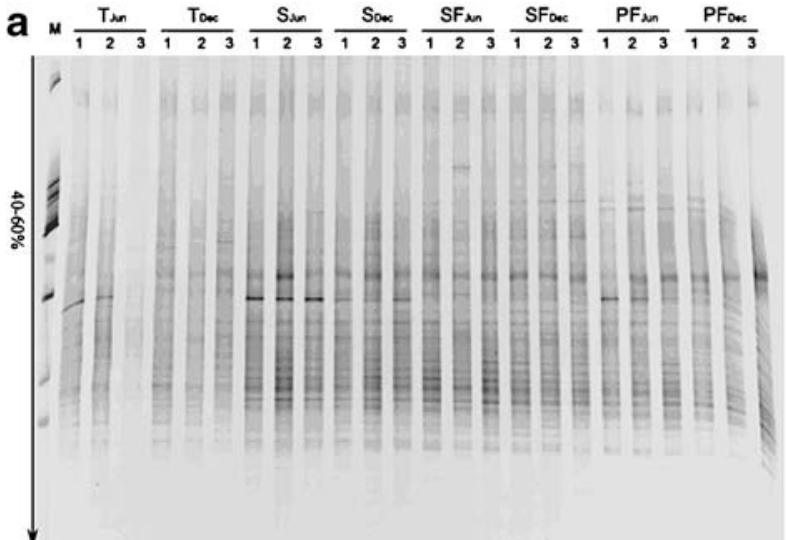

Fig. 1 DGGE community fingerprints of PCR amplified bacterial 16S (a) and fungal 18S (b) rDNA fragments from secondary vegetation succession stages. Capital letters denote vegetation successional stages ( $T$ tussock, $S$ shrub, $S F$

Univariate tests for different PCs indicated that three groups ( $\mathrm{T}$, SJun and the others) showed significant differences $(p<0.05)$ in Post Hoc Tests on PC1 (Fig. 3).

Differences in microbial taxonomic and metabolic diversity

Vegetation and season, as well as their interaction, had significant effects on bacterial taxonomic diversity $(p<0.05, p<0.001, p<0.05$, respectively), as well as fungal taxonomic diversity $(p<0.001, p<0.001, p<$ 0.01 , respectively); vegetation and the interaction of vegetation and season $(p<0.001, p<0.05$, respectively), but not season, had significant effects on bacterial metabolic diversity (Table 3).

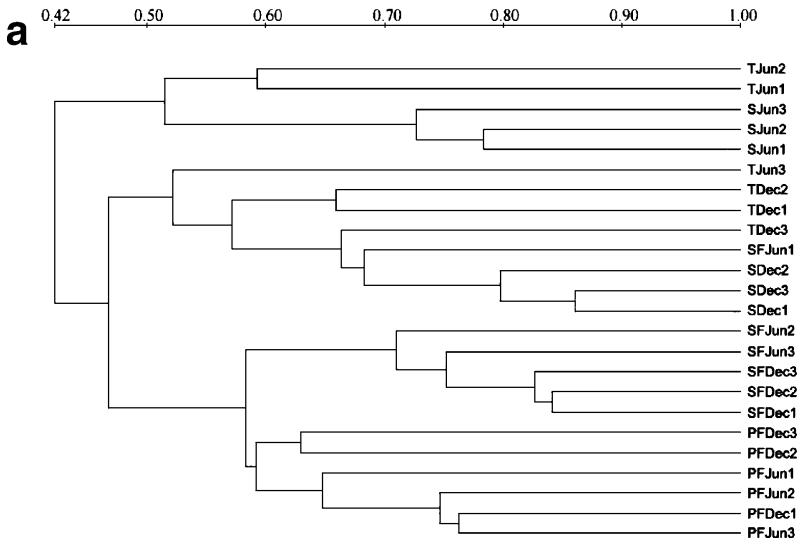

Fig. 2 UPGMA cladograms based on Dice similarity of bacterial (a) and fungal (b) community composition of soils from different vegetation successional stages and seasonal sampling times (for abbreviations and PCR-DGGE profiles see Fig. 1)
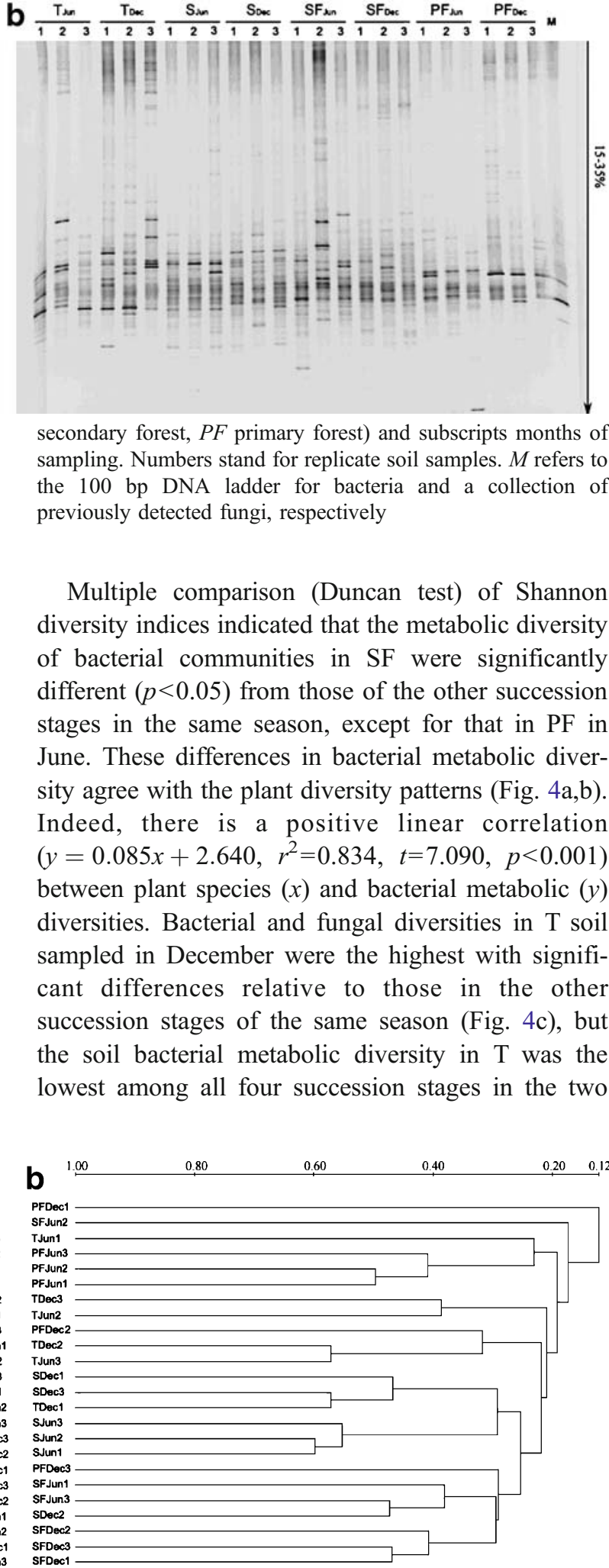

secondary forest, $P F$ primary forest) and subscripts months of sampling. Numbers stand for replicate soil samples. $M$ refers to the $100 \mathrm{bp}$ DNA ladder for bacteria and a collection of previously detected fungi, respectively

Multiple comparison (Duncan test) of Shannon diversity indices indicated that the metabolic diversity of bacterial communities in SF were significantly different $(p<0.05)$ from those of the other succession stages in the same season, except for that in PF in June. These differences in bacterial metabolic diversity agree with the plant diversity patterns (Fig. 4a,b). Indeed, there is a positive linear correlation $\left(y=0.085 x+2.640, r^{2}=0.834, t=7.090, p<0.001\right)$ between plant species $(x)$ and bacterial metabolic $(y)$ diversities. Bacterial and fungal diversities in $\mathrm{T}$ soil sampled in December were the highest with significant differences relative to those in the other succession stages of the same season (Fig. 4c), but the soil bacterial metabolic diversity in $\mathrm{T}$ was the lowest among all four succession stages in the two ) 


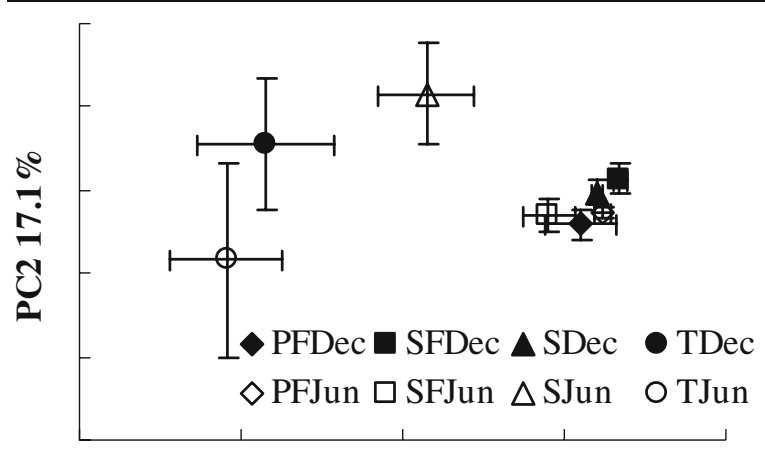

PC1 28.1\%

Fig. 3 Ordination biplot of a principal component analysis on the substrate utilization patterns of microbial communities from four vegetation successional communities derived from a Biolog_Eco plate assay. Shown are the means of three replicates with associated standard errors. For abbreviations of succession stages see Fig. 1

sampling seasons (Fig. 4b). In summer the bacterial diversities in all successional stages showed no significant differences among succession stages, but the soil fungal diversity in SF was significantly higher than in all other succession stages (Fig. 4c).

The soil bacterial and fungal diversity in $\mathrm{T}$, and bacterial diversity in $\mathrm{S}$, differed significantly between seasons (t-tests: $p<0.01, p<0.01, p<0.05$, respectively). However, soil microbial taxonomic diversities in $\mathrm{SF}$ and $\mathrm{PF}$, and fungal diversity in $\mathrm{S}$ had no significant seasonal shifts (Fig. 4c).

The Pearson's correlation analysis indicated that there was a strong positive correlation between bacterial and fungal Shannon diversities (Fig. 5). No significant correlations were found between soil microbial taxonomic and metabolic diversity (data not shown).

\section{Discussion}

Plant diversity and bacterial metabolic diversity

Aboveground and belowground components of terrestrial ecosystems have been shown to be closely linked (van der Heijden et al. 2008; Wardle et al. 2004). In our study, higher plant diversity correlated positively with higher bacterial metabolic diversity (Fig. 4a \& b). A possible mechanism behind this finding could be that higher plant diversity generally leads to higher plant biomass productivity (Cardinale et al. 2007), which could then lead to larger amounts of $\mathrm{C}$ entering the soil system (Liu et al. 2007). In fact, we found exactly the same ranking for plant diversity and SOM among the four succession stages (Table 2). Alternatively, an increase in plant richness and diversity could have led to greater resource heterogeneity in the soil (Rodríguez-Loinaz et al. 2008). Although the relationship between plant species diversity and plant productivity is still controversial (Chris and Richard 2006; Pärtel et al 2007), there are many published studies reporting higher productivity of species-rich relative to species-poor plant communities (Tilman and Downing 1994; Tilman et al. 1997).

Taxonomic diversity of plants and soil microbes

Although vegetation has significant effects on soil microbial taxonomic diversity (Table 3 ), the diversities of bacteria and fungi do not positively correlate with plant diversity along the vegetation succession (Fig. 4). Bacterial and fungal diversities were highest in $\mathrm{T}$ in December, but the plant species diversity was lowest in T among all four succession stages (Fig. 4a).

Table 3 Two-way ANOVA tables for the effect of vegetation type, season of sampling, and their interaction on bacterial and fungal taxonomic, and bacterial metabolic diversities $(\mathrm{H})$

\begin{tabular}{|c|c|c|c|c|c|c|c|c|c|}
\hline \multirow[t]{2}{*}{ Main effect } & \multicolumn{3}{|c|}{$\mathrm{H}^{\prime} \mathrm{bac}$} & \multicolumn{3}{|c|}{$\mathrm{H}^{\prime}$ fungi } & \multicolumn{3}{|c|}{ H'meta } \\
\hline & $d f$ & $F$ & $P$ & $d f$ & $F$ & $P$ & $d f$ & $F$ & $P$ \\
\hline Vegetation & 3 & 3.746 & $*$ & 3 & 15.125 & $* * *$ & 3 & 90.061 & $* * *$ \\
\hline Season & 1 & 29.001 & $* * *$ & 1 & 19.505 & $* * *$ & 1 & 0.176 & NS \\
\hline Vegetation $\times$ Season & 3 & 4.922 & $*$ & 3 & 8.566 & $* *$ & 3 & 5.358 & $*$ \\
\hline Residual & 16 & & & 16 & & & 16 & & \\
\hline Total & 23 & & & 23 & & & 23 & & \\
\hline
\end{tabular}

* Significant levels: $* * * P<0.001 ; * * P<0.01 ; * P<0.05$; NS not significant $(P>0.05)$ 

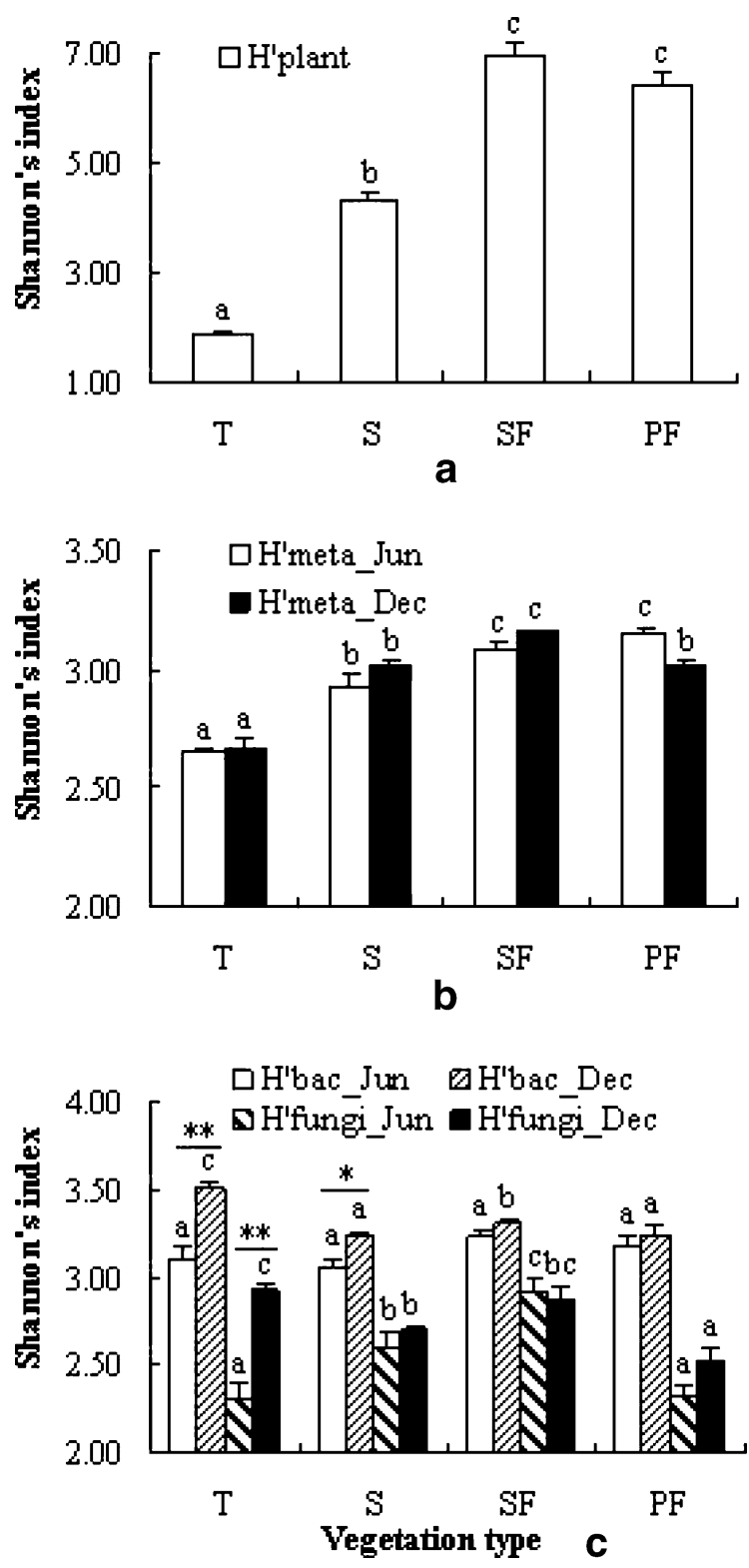

Fig. 4 Plant species (a) and soil bacterial metabolic Shannon diversities (b) and soil bacterial and fungal taxonomic diversities (c) at two sampling times in a secondary vegetation succession. Values represent the means of three replicates with associated standard errors. Different letters indicate a significant difference at $p<0.05$, according to Duncan tests. Significant seasonal variation of soil bacterial and fungal taxonomic diversities (c) for four soil microbial communities by the independent samples t-test are shown as a short line and $*(* * P<$ $0.01 ; * P<0.05)$, all non-significant seasonal diversity comparisons were omitted. For vegetation type abbreviations see Fig. 1
As the main primary producers in terrestrial ecosystems, plants are thought to have profound effect on soil communities and processes, especially those in the rhizosphere (Bever 1994, 2002; Wilson and Hartnett 1997). Consequently, changes in nutrient quality and availability caused by changes in plant diversity are expected to alter the number, activities and diversity of soil microorganisms (Hooper et al. 2000). Although each stage of succession was characterized by a particular plant species assemblage, Chabrerie et al. (2003) found that microbial communities show a degree of resilience with respect to changes in plant community composition. Similarly, our findings show that there is no direct link between plant and microbial taxonomic diversity.

Taxonomic structure of bacterial and fungal communities

The soil bacterial communities in $\mathrm{T}$ and $\mathrm{S}$ were more similar to each other than those in SF and PF. This indicates that soil bacterial communities may show successional changes that follow those in aboveground vegetation as reported by Kardol et al. (2007). More variability in the soil bacterial communities of replicate samples from $\mathrm{T}$ and $\mathrm{S}$ than samples from SF and PF may indicate that there were more different niches in the oligotrophic environments of $\mathrm{T}$ and $\mathrm{S}$ (Table 1). In contrast to bacteria, the fungal communities generally showed more variability and more distinctly dominant ribotypes, which is in agreement with the results of Costa et al. (2006).

The significant positive correlation between the bacterial and fungal diversities points at the existence

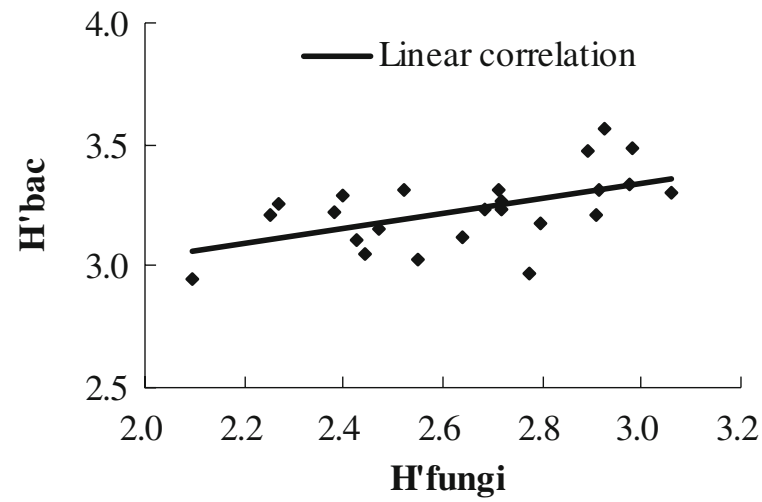

Fig. 5 Relationship fungal and bacterial diversities $\left(\mathrm{H}^{\prime}\right)$. Linear correlation: $y=0.319 x+2.387\left(r^{2}=0.305, p=0.005\right)$ 
of a close relationship between these two groups of microorganisms in the studied soils. Fungi can be important in shaping the soil bacterial assemblages in trophic web interactions (Singh et al. 2008). Artursson et al. (2005) demonstrated selection of distinct bacterial populations following inoculation of the AM fungus Glomus mosseae in soils and, a direct effect of mycelia exudates on bacterial assemblage was found in culture (Toljander et al. 2007). Moreover, fungi can act as vectors for bacterial migration (Kohlmeier et al. 2005).

Relationship between bacterial taxonomic diversity and metabolic diversity

No positive correlations between taxonomic and metabolic diversity were found, which is in accordance with some previous studies. For example, O'Donnell et al. (2001) suggested that factors other than community structure, such as soil $\mathrm{pH}$, were more important in regulating metabolic activity. The most likely explanation for a lacking correlation between bacterial taxonomic and metabolic diversity is that bacteria and fungi possess dormant growth stages (Chabrerie et al. 2003) and that DNA approaches capture the whole and not only the physiologically active communities. In general, depending on the conditions of nutrient supply, only a fraction of the microbes in soils are active (Chabrerie et al. 2003), whereas the large majority is either dormant or dead (McGill et al. 1986). This inactive part of the total microbial communities contributes to the soil 'memory' (Chabrerie et al. 2003). In agreement with this, Sharma et al. (2006) found that napA and nirS DGGE profiles derived from DNA showed no changes, whereas those from cDNA showed a clear succession of denitrifying bacteria. Moreover, different groups of soil microbes show metabolic redundancy, which means that any loss of microbial taxonomic diversity does not necessarily have to result in loss of metabolic functions (Wertz et al. 2006).

\section{Seasonal variation}

Bacterial and fungal taxonomic diversities differed (Fig. 4c; Table 3) between seasons, which agrees with previous findings of seasonal shifts in microbial communities (Schmidt and Lipson 2004; Monson et al. 2006; Wallenstein et al. 2007). Seasonal variation in the supply of substrates for microbial growth was found to shift from carbon polymers/phenolics (winter) to proteins (snowmelt) to rhizodeposition (summer) (Schmidt et al. 2007). However, bacterial metabolic diversity in this study did not differ between winter and summer (Table 3 ). The observation of seasonal shifts in microbial taxonomic diversity, but not in metabolic diversity may point at the existence of changes in microbial dormancy and metabolic redundancy. Occurrence of seasonal variation of microbial taxonomic differed between succession stages as assessed by independent t-tests (Fig. 4c). We may hypothesize that in the more oligotrophic T soil (Table 1) more r-selected microbes with more pronounced seasonal population shifts were favored, leading to the significant seasonal differences in taxonomic diversity. On the contrary, we may imagine that the more steady and copiotrophic soil environments in SF and PF favored more K-selected organisms (Fierer et al. 2007), showing more constant community compositions over vegetation seasons. However we found bacterial metabolic diversity in PF to differ significantly between seasons. Seasonal litters fall in the deciduous forest PF may explain seasonal differences in bacterial metabolic diversity in this succession stage, but not in the evergreen forest SF.

As it appears from unchanged bacterial metabolic diversities in T, S and SF, litter leaching (Qiu et al. 2005) and organic matter decomposition (Schmidt et al. 2007; Zogg et al. 1997) during the plant growth season (summer) were no determinant factors of bacterial activities in our study sites. Similarly, changes in soil moisture content that may have occurred were previously found not to explain the activity of microbial communities (Bossio et al. 1998; Krave et al. 2002). Irrespective of the season, differences in plant community composition appeared to explain differences in bacterial metabolic diversity in the present and a previous field study (Rogers and Tate 2001).

The microbial community from the $\mathrm{S}$ succession stage is special in so far as the bacterial taxonomic diversity, indeed, showed significant seasonal changes (Fig. 4c), whereas neither the fungal taxonomic, nor the bacterial metabolic diversity did so. Compared to $\mathrm{T}$ the soil environment of $\mathrm{S}$ appears to have been relatively more seasonally stable, because in $\mathrm{T}$ there were significant seasonal changes in bacterial and fungal taxonomic diversities. No seasonal differences 
were found for the SF and PF succession stages. This shows that with plant succession development metabolic functioning of soil microbial communities become more stable over plant growth seasons and that bacteria are more susceptive than fungi to seasonal fluctuations in the soil environment. With respect to bacterial CLPPs it is interesting to note that the succession stage $\mathrm{S}$ lay in between of the old (SF and $\mathrm{PF}$ ) and young (T) succession stages in summer and was more similar to SF and PF in winter (Fig. 3). This may show that competition among metabolic functional groups could be important in successionally intermediate bacterial communities when the availability of nutrient resources changes over the seasons.

\section{Summary}

In summary, this study showed that bacterial metabolic, but not taxonomic diversity can follow an increase in plant diversity. Moreover, we found evidence pointing towards an increased seasonal stability of soil bacterial metabolic diversity over successional plant community development. Seasonal differences in microbial taxonomic and metabolic diversity were more often found in younger than older plant succession stages. Finally, our field survey showed that bacterial and fungal taxonomic diversity can be correlated. We conclude that apparent anthropogenic impacts on the integrity of plant community diversity may be paralleled by changes to the soil microbial community and that metabolic functioning of bacterial communities in disturbed environments (reflected by younger succession stages) may become less stable over the plant growth season, with yet unknown consequences.

Acknowledgements We thank Zongming Su (Guangxi Institute of Botany, Guangxi Zhuangzu Autonomous Region and the Chinese Academy of Sciences, China) and Yuanhe Huang (Youjiang Medical College for Nationalities) for their assistance in the vegetation survey. Many thanks to Jizheng He, Yong Zheng and Jupei Shen (Research Center for Eco-Environmental Sciences, the Chinese Academy of Sciences) for technical assistance with molecular analyses, and to Wenxue Wei, Pedro Rocha (Institute of Subtropical Agriculture, the Chinese Academy of Sciences) for their valuable comments on previous versions of the manuscript, and to two anonymous reviewers for their precious comments on the first submitted version of the manuscript. This project was supported by the National Key
Basic Research Development Foundation of China (no. 2006CB403208) and the Chinese Academy of Sciences Western Action Program (no.KZCX2-XB2-08) and the Western Light Program of Talent Cultivation of the Chinese Academy of Sciences.

\section{References}

Artursson V, Finlay RD, Jansson JK (2005) Combined bromodeoxyuridine immunocapture and terminalrestriction fragment length polymorphism analysis highlights differences in the active soil bacterial metagenome due to Glomus mosseae inoculation or plant species. Environ Microbiol 7:1952-1966

Bever JD (1994) Feedback between plants and their soil communities in an old field community. Ecology 75:1965-1977

Bever JD (2002) Host-specificity of AM fungal population growth rates can generate feed-back on plant growth. Plant Soil 244:281-290

Bossio DA, Scow KM, Gunapala N, Graham KJ (1998) Determinants of soil microbial communities: effects of agricultural management, season, and soil type on phospholipid fatty acid profiles. Microb Ecol 36:1-12

Bossio DA, Girvan MS, Verchot L, Bullimore J, Borelli T, Albrecht A, Scow KM, Ball AS, Pretty JN, Osborn AM (2005) Soil microbial community response to land use change in an agricultural landscape of western Kenya. Microb Ecol 49:50-62

Cardinale BJ, Wright JP, Cadotte MW, Carroll IT, Hector A, Srivastav DS, Loreau M, Weis JJ (2007) Impacts of plant diversity on biomass production increase through time because of species complementarity. PNAS 104:1812318128

Carney KM, Matson PA (2006) The influence of tropical plant diversity and composition on soil microbial communities. Microb Ecol 52:226-238

Chabrerie O, Laval K, Puget P, Desaire S, Alard D (2003) Relationship between plant and soil microbial communities along a successional gradient in a chalk grassland in north-western France. Appl Soil Ecol 24:43-56

Chris L, Richard F (2006) A resource-based conceptual model of plant diversity that reassesses causality in the productivity-diversity relationship. Glob Ecol Biogeogr 15:213224

Costa R, Götz M, Mrotzek N, Lottmann J, Berg G, Smalla K (2006) Effects of site and plant species on rhizosphere community structure as revealed by molecular analysis of microbial guilds. FEMS Microbiol Ecol 56:236-249

Crecchio C, Gelsomino A, Ambrosoli R, Minati JL, Ruggiero P (2004) Functional and molecular responses of soil microbial communities under differing soil management practices. Soil Biol Biochem 36:1873-1883

Crecchio C, Curci M, Pellegrino A, Ricciuti P, Tursi N, Ruggiero P (2007) Soil microbial dynamics and genetic diversity in soil under monoculture wheat grown in different long-term management systems. Soil Biol Biochem 39:1391-1400

De Deyn GB, Van der Putten WH (2005) Linking aboveground and belowground diversity. TREE 20:625-633 
Doran JW, Zeiss MR (2000) Soil health and sustainability: managing the biotic component of soil quality. Appl Soil Ecol 15:3-11

Ferris MJ, Muyzer G, Ward DM (1996) Denaturing gradient gel electrophoresis profiles of $16 \mathrm{~S}$ rRNA-defined populations inhabiting a hot spring microbial mat community. Appl Environ Microb 62:340-346

Fierer N, Bradford MA, Jackson RB (2007) Toward an ecological classification of soil bacteria. Ecology 88:1354-1364

Garland JL (1996) Patterns of potential C source utilization by rhizosphere communities. Soil Biol Biochem 28:223-230

Garland JL (1997) Analysis and interpretation of communitylevel physiological profiles in microbial ecology. FEMS Microbiol Ecol 24:289-300

Gelsomino A, Cacco G (2006) Compositional shifts of bacterial groups in a solarized and amended soil as determined by denaturing gradient gel electrophoresis. Soil Biol Biochem 38:91-102

Glimm E, Heuer H, Engelen B, Smalla K, Backhaus H (1997) Statistical comparisons of community catabolic profiles. J Microbiol Methods 30:71-80

Heuer H, Hartung K, Wieland G, Kramer I, Smalla K (1999) Polynucleotide probes that target a hypervariable region of $16 \mathrm{~s}$ rRNA genes to identify bacterial isolates corresponding to bands of community fingerprints. Appl Environ Microb 65:1045-1049

Hooper DU, Bignell DE, Brown VK, Brussaard L, Dangerfield JM, Wall DH, Wardle DA, Coleman DC, Giller KE, Lavelle P, Van der Putten WH, De Ruiter PC, Rusek J, Silver WL, Tiedje JM, Wolters V (2000) Interactions between aboveground and belowground biodiversity in terrestrial ecosystems: patterns, mechanisms, and feedbacks. Bioscience 50:1049-1061

Kardol P, Cornips NJ, Van Kempen MML, Bakx-Schotman JMT, Van Der Putten WH (2007) Microbe-mediated plant-soil feedback causes historical contingency effects in plant community assembly. Ecol Monogr 77:147-162

Klose S, Wernecke KD, Makeschin F (2004) Microbial activities in forest soils exposed to chronic depositions from a lignite power plant. Soil Biol Biochem 36:19131923

Kohlmeier S, Smits THM, Ford RM, Keel C, Harms H, Wick LY (2005) Taking the fungal highway: Mobilization of pollutant-degrading bacteria by fungi. Environ Sci Technol 39:4640-4646

Krave AS, Lin B, Braster M, Laverman AM, van Straalen NM, Röling WFM, van Verseveld HW (2002) Stratification and seasonal stability of diverse bacterial communities in a Pinus merkusii (pine) forest soil in central Java, Indonesia. Environ Microbiol 4(6):361-373

Li YB, Hou JJ, Xie DT (2002) The recent development of research on karst ecology in Southwest China (in Chinese). Scientia Geographica Sinica 22:365-370

Liu ZF, Liu GH, Fu BJ, Zheng XX (2007) Relationship between plant species diversity and soil microbial functional diversity along a longitudinal gradient in temperate grasslands of Hulunbeir, Inner Mongolia, China. Ecol Res. DOI 10.1007/s11284-007-0405-9

Lupway NZ, Rice WA, Clayton GW (1998) Soil microbial diversity and community structure under wheat as influ- enced by tillage and crop rotation. Soil Biol Biochem 30:1733-1741

Magurran AE (2004) Measuring biological diversity. Blackwell Publishing, Oxford, pp 107-130

May LA, Smiley B, Schmidt MG (2001) Comparative denaturing gradient gel electrophoresis of fungal communities associated with whole plant corn silage. Can J Microbiol 47:829-841

McGill WB, Cannon KR, Robertson JA, Cook FD (1986) Dynamics of soil microbial biomass and water soluble organic $\mathrm{C}$ in Breton $\mathrm{L}$ after 50 years of cropping to two rotations. Can J Soil Sci 66:1-19

Monson RK, Lipson DA, Burns SP, Turnipseed AA, Delany AC, Williams MW, Schmidt SK (2006) Winter forest soil respiration controlled by climate and microbial community composition. Nature 439:711-714

Müller AK, Westergaard K, Christensen S, Sørensen SJ (2002) The diversity and function of soil microbial communities exposed to different disturbances. Microb Ecol 44:49-58

Muyzer G, de Waal EC, Uitterlinden AG (1993) Profiling of complex microbial populations by denaturing gradient gel electrophoresis analysis of polymerase chain reactionamplified genes coding for 16S rRNA. Appl Environ Microb 59:695-700

Naeem S, Li SB (1997) Biodiversity enhances ecosystem reliability. Nature 390:507-509

O’Donnell AG, Seasman M, Macrae A, Waite I, Davies JT (2001) Plants and fertilizers as drivers of change in microbial community structure and function in soils. Plant Soil 232:135-145

Ou ZL, Li XK, Su ZM (2005) Population variation and species diversity in the succession process of karst vegetation in Yangshuo, Guangxi (in Chinese). Ecol Sci 24:295-297

Ouyang ZY (1998) On the comprehensive management, development and keeping away from poorness of the ecologically fragile karst area in south-west China (in Chinese). World Sci Tech Res Dev 20:53-56

Pan GX, Cao JH (1999) Karstification in epikarst zone: the earth surface ecosystem processes taking soil as a medium - case of the Yaji karst experiment site, Guilin (in Chinese). Carsologica Sinica 18:287-296

Pärtel M, laanisto L, Zobel M (2007) Contrasting plant productivity-diversity relationships across latitude: the role of evolutionary history. Ecology 88:1091-1097

Qiu S, McComb AJ, Bell RW, Davis JA (2005) Response of soil microbial activity to temperature, moisture, and litter leaching on a wetland transect during seasonal refilling. Wetlands Ecol Manag 13:43-54

Rodríguez-Loinaz G, Onaindia M, Amezaga I, Mijangos I, Garbisu C (2008) Relationship between vegetation diversity and soil functional diversity in native mixed-oak forests. Soil Biol Biochem 40:49-60

Rogers BF, Tate RL (2001) Temporal analysis of the soil microbial community along a toposequence in Pineland soils. Soil Biol Biochem 33:1389-1401

Schmidt SK, Lipson DA (2004) Microbial growth under the snow: implications for nutrient and alleochemical availability in temperate soils. Plant Soil 259:1-7

Schmidt SK, Costello EK, Nemergut DR, Cleveland CC, Reed SC, Weintraub MN, Meyer AF, Martin AM (2007) Biogeochem- 
ical consequences of rapid microbial turnover and seasonal succession in soil. Ecology 88:1379-1385

Scow KM, Bruns MA, Graham K, Bossio D, Schwartz E (1998) Development of indices of microbial community structure for soil quality assessment. In: Zabel A, Sposito G (eds) Soil quality in the California environment. Kearney Foundation of Soil Science Annual Report of Research Projects 1997-1998. Kearney Foundation of Soil Science, USA, pp 110-123

Sharma S, Szele Z, Schilling R, Munch JC, Schloter M (2006) Influence of freeze-thaw stress on the structure and function of microbial communities and denitrifying populations in soil. Appl Environ Microbiol 72:2148-2154

Singh BK, Nunan N, Ridgway KP, McNicol J, Young JPW, Daniell TJ, Prosser JI, Millard P (2008) Relationship between assemblages of mycorrhizal fungi and bacteria on grass roots. Environ Microbiol 10:534-541

Tilman D (1999) The ecological consequences of changes in biodiversity: a search for general principles. Ecology 80:1455-1474

Tilman D, Downing JA (1994) Biodiversity and stability in grasslands. Nature 367:363-365

Tilman D, Knops J, Wedin D, Reich P, Ritchie M, Siemann E (1997) The influence of functional diversity and composition on ecosystem processes. Science 277:13001305

Toljander JF, Lindahl BD, Paul LR, Elstrand M, Finlay RD (2007) Influence of arbuscular mycorrhizal mycelial exudates on soil bacterial growth and community structure. FEMS Microbiol Ecol 61:295-304

van der Heijden MGA, Bardgett RD, van Straalen NM (2008) The unseen majority: soil microbes as drivers of plant diversity and productivity in terrestrial ecosystems. Ecol Lett 11:296-310

Vitousek PM, Aber JD, Howarth RW, Likens GE, Matson PA, Schindler DW, Schlesinger WH, Tilman DG (1997)
Human alteration of the global nitrogen cycle: sources and consequences. Ecol Appl 7:737-750

Wallenstein MD, McMahon S, Schimel J (2007) Bacterial and fungal community structure in Arctic tundra tussock and shrub soils. FEMS Microbiol Ecol 59:428-435

Wardle DA, Bardgett RD, Klironomos JN, Setälä H, van der Putten WH, Wall DH (2004) Ecological linkages between aboveground and belowground biota. Science 304:16291633

Weber KP, Grove JA, Gehder M, Anderson WA, Legge RL (2007) Data transformations in the analysis of communitylevel substrate utilization data from microplates. J Microbiol Methods 69:461-469

Wertz S, Degrange V, Prosser JI, Poly F, Commeaux C, Freitag T, Guillaumaud N, Le Roux X (2006) Maintenance of soil functioning following erosion of microbial diversity. Environ Microbiol 8:2162-2169

Wilson GWT, Hartnett DC (1997) Effects of mycorrhizae on plant growth and dynamics in experimental tallgrass prairie microcosms. Am J Bot 84:478-482

Yao CH, Jiang ZC, Yuan DX (2001) Vegetation effects on karst physiognomy in southwest China (in Chinese). Acta Geoscientia Sinica 22:159-164

Yao HY, Bowman D, Shi W (2006) Soil microbial community structure and diversity in a turfgrass chronosequence: land-use change versus turfgrass management. Appl Soil Ecol 34:209-218

Yuan DX (1991) Karst of China. Geological Publishing House, Beijing, p 1-9

Zak JC, Willig MR, Moorhead DL, Wildman HG (1994) Functional diversity of microbial communities: a quantitative approach. Soil Biol Biochem 26:1101-1108

Zogg GP, Zak DR, Ringelberg DB, MacDonald NW, Pregitzer KS, White DC (1997) Compositional and functional shifts in microbial communities due to soil warming. Soil Sci Soc Am J 61:475-481 